\title{
The Effect of Erosion Control Practices on the Vulnerability of Soil Degradation in Oued EL Malleh Catchment using the USLE Model Integrated into GIS, Morocco
}

\author{
Nouhaila Mazigh ${ }^{1, *}$, Abdeslam Taleb ${ }^{1}$, Ali El Bilali ${ }^{1}$ and Abderrahmane Ballah ${ }^{2}$ \\ ${ }^{I}$ Department of Process Engineering and Environment, Hassan 2 University, \\ Faculty of Sciences and Techniques, Mohammedia, Morocco \\ ${ }^{2}$ Laboratory of Water and Environment, University Center of Tamanrasset, \\ Hassiba Benbouali University of Chlef, Algeria
}

('Corresponding author's e-mail: nouhailamazigh@gmail.com)

Received: 2 September 20202, Revised: 23 April 2021, Accepted: 2 May 2021

\begin{abstract}
Water erosion is a major problem in semi-arid region where decreases the dam reservoir design capacity, agricultural yield productivity, and increases other environmental impacts. This phenomenon is widely predominant in Morocco, particularly in the Oued El Malleh watershed in the Casablanca Settat region. Most soil erosion happens gradually which makes it challenging to notice. Hence, the monitoring of soil degradation under a modelling-based, such as Geographic Information System (GIS) can help the decision-makers to quantify the eroded soil and choose the best mitigation measures. Many erosion control practices have been implemented in The Oued El Malleh watershed in 2008, which covers a surface area of $3,127 \mathrm{~km}^{2}$. Even though, the soil erosion still dramatic in the region. To date, no one has attempted to work on the impact of the soil conservation factor at the level of the Oued El Malleh watershed, as well as monitoring the sustainability and effectiveness of the water erosion control practices already implemented. Therefore, periodic monitoring and evaluating soil degradation is imposed. To achieve this purpose, we used the Universal Soil Loss Equation (USLE) to spatially assess water erosion in the study area, to find out the most vulnerable area to erosion, to notice the efficiency of the actual erosion control practices and elaborate on new mitigation measures. The results of this study have been shown that the rate of soil loss in the Oued El Malleh, including the actual control erosion interventions, varies from 0 to $90 \mathrm{t}$. $\mathrm{ha}^{-1}$.year ${ }^{-1}$; with an average erosion rate of $0.65 \mathrm{t}$. $\mathrm{ha}^{-1}$.year ${ }^{-1}$. The study area characterized by a moderate to severe slopes, in some area, the Length and Steepness Factor LS exceeds $90 \%$. For this reason, we have been elaborated new soil loss map, including soil conservation measures according to the slope. The soil loss rate; following this approach; varies from 0 to 64 t.ha $^{-1}$. year ${ }^{-1}$. Furthermore, the followed approach could be valuable for assessing the soil loss in similar area.
\end{abstract}

Keywords: Soil erosion, USLE, Remote sensing, Morocco, Soil degradation

\section{Introduction}

Water erosion is a dynamic process of detachment, transport and deposition of soil particles under the effect of the kinetic energy of water [1]. It is a multidimensional natural hazard and environmental challenge to the ecosystem, threatening, especially the potential of water and soil. It is among the most disturbing phenomenon for watershed management. This is triggered by a complex interaction of processes due to many factors such as natural (climate, topography, soil, vegetation) and anthropogenic (tillage systems, soil conservation measures, overgrazing and deforestation). Leading to the exposure of land runoff [2,3] and thus, reducing the productivity of agricultural land [4], degradation of the quality and quantity of water available accelerating the rate of sedimentation [5], the impacts of these phenomena negatively affect the country's economy; especially Morocco is economically based on agriculture and water resources. Therefore, evaluation of the soil erosion at watershed scale could be valuable for the decision-makers to prioritize and to implement sustainable actions in managing and planning of the watershed to reduce the soil loss. For 6 decades, several empirical-based models have been developed and applied by the researchers. For instance, Wischmeier and Smith [6] developed and applied USLE in 1978. Renard et al. [7] revised the USLE by introducing the isoerodent maps, a time-varying approach for soil 
erodibility factor, a sub factor approach for evaluating the cover management factor, a new equation to reflect slope length and steepness and lastly is new conservation-practice values. All of these improvements developed the Revised Universal Soil Loss Equation (RUSLE). Similarly, Bhandari and Darnsawasdi [8], have been mapped soil erosion in the Phewa watershed in Nepal using the REUSLE coupled with Participatory geographic information system (PGIS) based on Erosion Damaged Assessment (EDA). Besides, in 1972 developed Modified USLE (MUSLE) to overcome the USLE and RUSLE limitations. Several studies applied MUSLE for evaluating the soil loss and reservoir sedimentation in semi-arid. For instance, Bilali et al. [9] applied MUSLE model to evaluate the soil erosion in Bouregreg watershed and showed it applicability in semi-arid environment rely on it calibration form. Nonetheless, empirical modelling is not always satisfactory, especially against water erosion and sedimentation processes. In this regard, new technologies have been developed such as the Water Erosion Prediction Model (WEPP), Soil and Water Assessment Tool (SWAT) and Pan European Soil Erosion Risk Assessment (PESERA) models [10]. Several works have been applied the physicallybased models, among those, Shivhare et al. [11] have been applied the SWAT model to estimate the runoff, sediment yield, and evapotranspiration in the Ganga river watershed, in India. Other studies used WEEP model to quantify the rill erosion and to evaluate the impact of hydraulic parameters of the flow on the soil properties [12], further research have been highlighted the application of PESERA model, which is useful tool to comprehend the relationship between the input and output data scale, and their impact on water erosion modelling and sediment yield [13]. However, those models need calibration and validation and require a time series of the sediment yield and rainfall runoff data [14]. Wherefore, using the USLE model for non-gauged watersheds could be valuable in overcoming the measurement issue for MUSLE calibration. Indeed, there are a lot of the studies that applied USLE in semi-arid environment Such as in the Ikkour watershed, in the Middle Atlas Mountain (Morocco); where the USLE model was used combined with spectral indices approach to share more information about levels of soil degradation and the sensitivity of the study area against water erosion [9]. Similarly, in Machados County, Brazil, Falcão et al. [15] used USLE, GIS and remote sensing data to estimate the potential of sheet erosion in this agricultural terrain. Furthermore, the soil loss, was calculated from the USLE equation with a several models, which have been developed to determine the impact of climate and land use in the Luanhe River Basin (LRB), China [16]. On top of that, in Estepa Region (Southern, Spain), USLE equation was integrated with cartography to evaluate the soil erosion levels on the olive grove farms, to help farmers to choose the olive management model, and to ensure the sustainability of agricultural activity of the olive crop [17].

In Morocco, $40 \%$ of the land is affected by water erosion [18]. In the parts of the Rif mountains of Morocco, erosion rates reach sometimes 30 to $60 \mathrm{t} / \mathrm{ha} /$ year [19,20] and reach $2000 \mathrm{t} / \mathrm{km}^{2} /$ year (for the Central and Western Rif) [21]. In Middle and High Atlas, the annual average of erosion rate is ranging from 500 to $1000 \mathrm{t} / \mathrm{km}^{2} /$ year and from 1000 to $2000 \mathrm{t} / \mathrm{km}^{2} /$ year in (the Pre-Rif and the Mediterranean border .(Therefore, dams lose their initial capacity of the water storage due to their silting which is estimated at $0.5 \%$ per year [22]. The biggest Moroccan dams receive annually about 50 million tons of sediment [23], which affects their storage capacity and an annual loss of nearly 300 million Dirhams [24]. The Oued El Malleh watershed covers a surface area of $3127 \mathrm{~km}^{2}$ characterized by vast expanses of agricultural land with small thick vegetation areas. Indeed, the watershed influenced by a harsh climate, distribution of impermeable lithologic formations, moderate to severe topography, and impact of anthropogenic activities. Those factors increase the vulnerability of the study area to water erosion.

The effect of these constraints, especially, appears downstream of the watershed by reducing the holding capacity of the dam Oued El Malleh and leaching nutrients from agricultural land.

The objective of this study is to investigate the susceptibility to water erosion, of Oued El Malleh catchment through Empirical Universal Soil Loss Equation (USLE). This objective could be carried out by 1) mapping the soil erosion factors, namely the aggressiveness of precipitation, erodible soils, topography, land use, and crop management, 2) identifying the areas vulnerable to erosion, and 3) choosing the most appropriate soil conservation measures.

\section{Materials and methods}

\section{Study area description}

The river's watershed El Malleh is located in the Northeast region of Casablanca and more precisely between the cities of Mohammedia (place of its outlet) and Khouribga, between latitudes 33.00 and 33.71 north, longitude 6.45 and 6.55 west. This is a watershed with an approximate area of $3127 \mathrm{~km}^{2}$ (Figure 1). The watershed of Oued El Malleh landscape is a relatively steep with an average slope of about $8.7 \%$; 
it has hilly landscapes with altitudes ranging from 0 to $966 \mathrm{~m}$ and the outlet (Figure 2). The slope map is derived from the digital elevation model (DEM) (Figure 3), and the distribution of slope class by area is summarized in the following (Table 1).

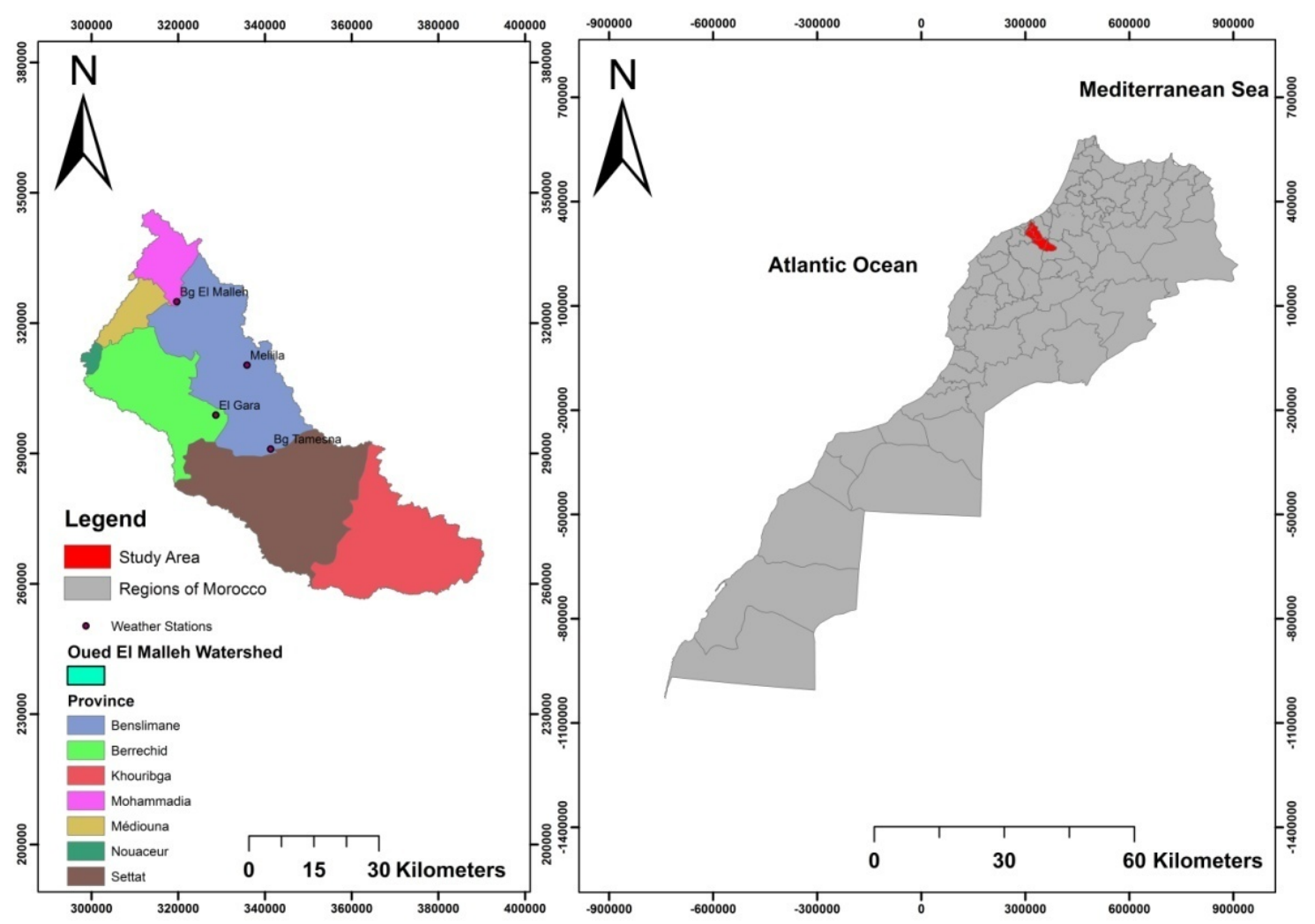

Figure 1 Study area map.

Table 1 Distribution of slope classes.

\begin{tabular}{cccc}
\hline Class & Class of slopes \% & Areas (ha) & Areas (\%) \\
\hline 1 & $0-3$ & $102,480.02$ & 32.77 \\
2 & $3-7$ & $132,514.653$ & 42.38 \\
3 & $7-13$ & $50,052.5614$ & 16.01 \\
4 & $13-21$ & $19,732.9244$ & 6.31 \\
5 & $>53$ & $7,923.91347$ & 2.53 \\
\hline
\end{tabular}

Table 1 from the slope map, highlights the division of the watershed into 3 main areas:

1) Low slope zones $(0-7)$ extend about $75.15 \%$ of the total area of the basin;

2) Slightly rough ( 7 - 53) covering $22.32 \%$ of the total area of the basin;

3) Very rugged and steep-sided (over 53) occupy only $2.53 \%$ of the total basin area.

The watershed of Oued El Malleh belongs to the Mediterranean climate that is characterized by the domination of 2 contrasting seasons:

1) Season hot and dry climate (summer);

2) Season wet and temperate climate (winter).

The catchment area receives rainfall amounts ranging from one region to another, by the intervention of 2 important factors: Continentality and altitude. In general, the average annual rainfall varies between 270 and $550 \mathrm{~mm}$ [25]. However, the runoff varies from one hydrological event to another where some event can led to the flood disasters indicating a high variability of the runoff [26]. 


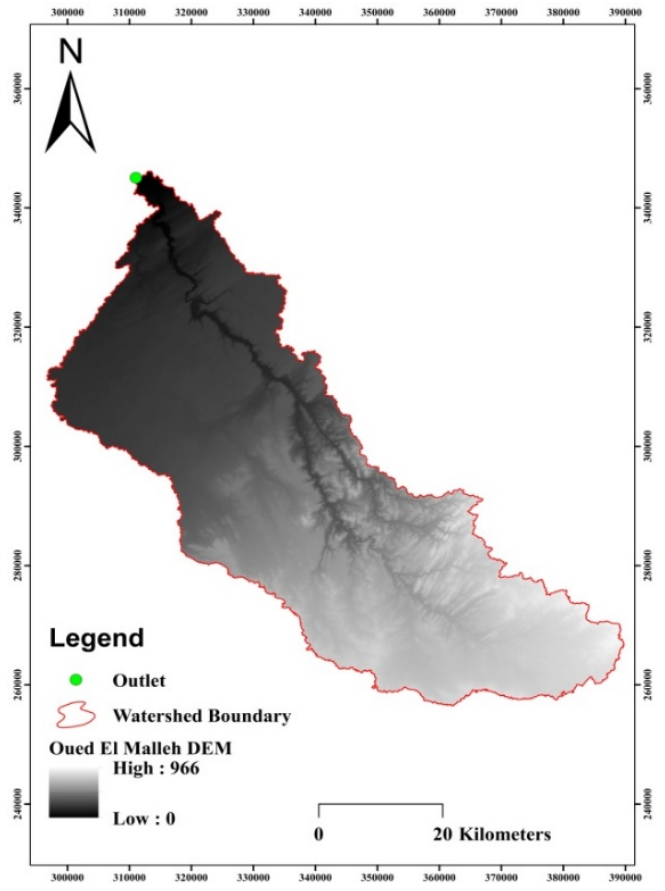

Figure 2 Digital elevation model (DEM).

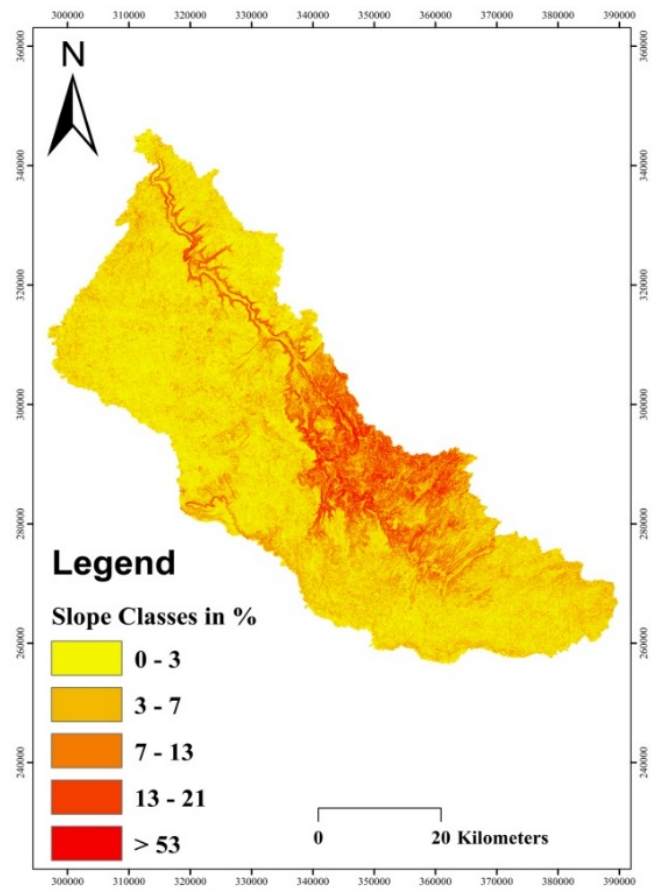

Figure 3 Slope classes in percentage (\%).

\section{Dataset}

The Universal Soil Loss Equation (USLE) was proposed by $[13,15]$ to predict the scale of water erosion of cultivated fields and small watersheds. This model on the US media conditions aims to link the measurable parameters of physical phenomena [27]. The USLE equation meets the factors that determine soil loss topography (LS), the climatic aggressiveness (R), soil erodibility (K), and vegetation cover (C), the erosion control techniques (P). Although USLE is widely used in the scientific world, this equation has some limitations and requires calibration parameters that are not always available. Furthermore it applies only to sheet erosion [28].

The USLE equation is a product of 5 input factors in raster data format: Soil erodibility; rainfall erosivity; slope length and steepness; cover management; and support practice. Each factor varies over time and space and depends on other input data. Therefore, soil erosion within each pixel was calculated using the Universal Soil Loss Equation (USLE) [29].

The USLE equation is described as;

$\mathrm{A}=\mathrm{R} * \mathrm{~K} * \mathrm{LS} * \mathrm{C} * \mathrm{P}$

where A is the spatial average of calculated loss of soil over a selected period for R, usually on a yearly basis $\left(\mathrm{t} . \mathrm{ha}^{-1} \cdot \mathrm{y}^{-1}\right) ; \mathrm{R}$ is the rainfall erosivity factor (MJ.mm.ha ${ }^{-1} \cdot \mathrm{h}^{-1} \cdot \mathrm{y}^{-1}$ ); $\mathrm{K}$ is the soil erodibility factor (t.ha.h.ha ${ }^{-1} \cdot \mathrm{MJ}^{-1} \cdot \mathrm{mm}^{-1}$ ); LS is the slope factor (dimensionless); $\mathrm{C}$ is the vegetation cover factor (dimensionless, between 0 and 1); and $\mathrm{P}$ is the erosion control practices factor (dimensionless, between 0 and 1).

The followed methodology requires data on erosive factors, therefore to conduct the study; we have used the following data;

Map data;

1) The digital elevation model DEM with a resolution of $30 \mathrm{~m}$, for the development of several thematic maps :The map of the river system, the slope map.

2) The soil map was scanned from the agricultural map in 1/500000 scale, provided by the organization of the United Nations Food and Agriculture [30], it was used for determining the factor of soil erodibility (K) of the erosion model Wischmeier (USLE).

3) The satellite Landsat 8 OLI was extracted mainly from United States Geological Survey's Earth Explorer [31] collect and publish by Shuttle Radar Topography Mission, to determine land use in the area of study. 
Data erosion control interventions: The erosion control measures applied to the watershed of Oued El Malleh were taken to the Regional Directorate of Water and Forests and the fight against Desertification (Casablanca, Morocco).

Climatic data: Rainfall was extracted from meteorological data of the Hydraulic Basin Agency of Bouregreg and Chaouia (Benslimane, Morocco).

\section{Methodology approach}

The methodology focused on the use of the USLE equation integrated into a GIS environment. All the USLE factors were derived and processed in ArcGIS version 10.2 with a $30 \mathrm{~m}$ pixel size. Soil loss had estimated by the multiplication of the 5-factor maps in the Raster calculator.

\section{Soil erosion equation}

Different approaches have been used to assess the soil erosion risk, including empirical erosion models [32,33], a ranking method based on selected indicators such as percentage of bare ground, aggregate stability, organic carbon, percentage clay, and bulk density [34] and qualitative erosion risk mapping based on the combination of 5 factors namely geology, soil, relief, climate and vegetation. The most widely used model is the USLE [6] expressed as follows Eq. (1).

\section{The erosive power of rainfall $R$}

The climate favours aggressive erosion, which leads to give the climate a devastating effect [35]. The action of precipitation amplifies the driving forces needed to pull of soil particles. The index (R) expresses the ability of rain to erode. Rains, by their intensity and energy are the main factor determining the loss of land. The rainfall erosivity for a rain event was determined by the following equation [6];

$\mathrm{R}=\mathrm{KE} * \mathrm{I}_{30}$

Where KE is the kinetic energy of raindrops in (Joules) and $\mathrm{I}$ : is the maximum rain intensity for 30 consecutive minutes expressed in $\left(\mathrm{mm} \cdot \mathrm{h}^{-1}\right)$.

These formulas proposed by [6] as erosive indicator is difficult to apply in areas where the rainfall data are not regular. For areas that do not have detailed climate data, the R factor can be estimated using a modified Fournier index (F). [36] Proposed a modified form of the index of Fournier to avoid the disadvantages associated with the monthly distribution of erosive rainfall during the year, and was used to establish risk areas erosion in North Africa and the Middle East by FAO [37].

$\mathrm{R}=0.264 * \mathrm{~F}^{1,5}$

Where $\mathrm{R}$ is the rainfall erosivity factor $\left(\mathrm{MJ} \cdot \mathrm{mm} \cdot \mathrm{ha}^{-1} \cdot \mathrm{h}^{-1} \cdot \mathrm{y}^{-1}\right)$ and $\mathrm{F}$ is the index of Fournier.

With,

$F=\sum_{i=1}^{12} \frac{r i * r i}{P}$

Where ri is a monthly precipitation ( $\mathrm{mm})$ and $\mathrm{P}$ is the annual precipitation $(\mathrm{mm})$.

\section{Soil erodibility factor $\mathrm{K}$}

The erodibility factor $(\mathrm{K})$ expresses soil cohesion and soil strength against the erosion. It depends on the soil texture, structure, its organic matter content and its permeability, according to [6];

$\mathrm{K}=2.1 * \mathrm{M}^{1.14} * 10^{-6} *(12-\mathrm{M} 0)+0.0325 *(\mathrm{~b}-2)+0.025 *(\mathrm{c}-3)$

Where $\mathrm{K}$ is the soil erodibility factor (t.ha.h.ha $\left.{ }^{-1} \cdot \mathrm{MJ}^{-1} \cdot \mathrm{mm}^{-1}\right), \mathrm{M}$ is the particles percentage (\% of very fine sand $+\%$ of silt $x(100 \%$ clay $))$, MO is the percentage of organic matter, $b$ is the soil structure code and $\mathrm{c}$ is the soil permeability. 
Since no data on the index $\mathrm{c}$ and $\mathrm{b}$ value, the factor $\mathrm{K}$ was calculated by the Wiliam formula [38];

$\mathrm{K}_{\text {usle }}=\mathrm{K}_{\mathrm{w}}=\mathrm{f}_{\text {csand }} * \mathrm{f}_{\mathrm{cl}-\mathrm{si}} * \mathrm{f}_{\text {org }} * \mathrm{f}_{\text {hisand }}$

where $\mathrm{K}$ is the soil erodibility factor (t.ha.h.ha ${ }^{-1} \cdot \mathrm{MJ}^{-1} \cdot \mathrm{mm}^{-1}$ ), $\mathrm{f}_{\mathrm{csand}}$ is a factor that decreases the $\mathrm{K}$ indicator in soils high in coarse sand and little higher in sandy soils, $\mathrm{f}_{\mathrm{cl}-\mathrm{si}}$ provides low soil erodibility factors for soils with high clay silt reports, $\mathrm{f}_{\text {org }}$ reduced $\mathrm{K}$ values in soils rich in organic carbon andf $_{\text {hisand }}$ : Lowers the values of $\mathrm{K}$ for extremely sandy.

Each factor is calculated according to the formulas shown below;

$$
\begin{aligned}
& \mathrm{f}_{\text {csand }}=0.2+0.3 * \exp \left(-0.256 * \mathrm{~ms} *\left(1-\frac{\mathrm{msilt}}{100}\right)\right) \\
& \mathrm{f}_{\mathrm{cl}-\mathrm{si}}=\left(\frac{\mathrm{msilt}}{\mathrm{mc}+\mathrm{msilt}}\right)^{0.3} \\
& \mathrm{f}_{\text {org }}=\left(1-\frac{0.25 * \text { orgC }}{\text { orgC+exp(3.72-2.95*orgC })}\right) \\
& \mathrm{f}_{\text {hisand }}=\left(1-\frac{0.7 *\left(1-\frac{\mathrm{ms}}{100}\right)}{\left(1-\frac{\mathrm{ms}}{100}\right)+\exp \left(-5.51+22.9 *\left(1-\frac{\mathrm{ms}}{100}\right)\right)}\right)
\end{aligned}
$$

where ms: Sand fraction content $(0.05-2.00 \mathrm{~mm}$ diameter $)(\%), \mathrm{m}$ silt: Silt content of fraction $(0.002-$ $0.05 \mathrm{~mm}$ in diameter) $(\%), \mathrm{mc}$ : The clay fraction content (diameter $<0.002 \mathrm{~mm})(\%)$, and orgC: the organic carbon (SOC) $(\%)$.

The results of K are in (ton/acre) (US system), and need to be converted into the international system, for this a 0.1317 factor is multiplied to each value of $\mathrm{K}$.

\section{Topographical factors LS}

The length, shape and especially the inclination of slope are parameters that significantly influence soil erosion [39]. The slope length determines the runoff velocity and transport of particles increases with the length of the plot [25-27]. The factors L (slope length) and S (slope angle in \%) are usually combined into a single dimensionless factor LS to define the effect of sheet erosion and rill [42].

Several formulas have been adopted to calculate these 2 parameters. In our case, the LS topographic factor was calculated directly in ArcGIS software from the digital elevation model (DEM) of the $30 \mathrm{~m}$ resolution of study area, the slope map classes in (\%) and the card accumulation of flux according to the formula [6];

$\mathrm{LS}=\left(\mathrm{FA} *\left(\frac{\text { cellsize }}{22.13))^{\mathrm{m}}} *\left(0.065+0.045 * \mathrm{~S}+0.065 * \mathrm{~S}^{2}\right)\right.\right.$

where LS is the slope-length factor, FA is the flow-accumulation, cell size is the length of grid or pixel size $(30 \mathrm{~m}$ for Landsat $8 \mathrm{OLI}), \mathrm{m}$ is a constant dependent on the value of gradient (Table 2 ) and $\mathrm{S}=$ slope in degrees.

Table 2 Slope gradient classes.

\begin{tabular}{cc}
\hline Percent grade (\%) & Factor $\mathbf{~}$ \\
\hline$\geq 5$ & 0.5 \\
$3.5 \leq \Theta<5$ & 0.4 \\
$1 \leq \Theta<3.5$ & 0.3 \\
$<1$ & 0.2 \\
\hline
\end{tabular}




\section{Land use factor $C$}

The vegetation is the most active factor in our study area, to control the risk of water erosion. It provides ground mechanical protection against removal by reducing the driving force of the water. The vegetation acts as a shield against the aggressive climate by intercepting the energy released by the raindrops [43].

The exposure of the soil by deforestation and overgrazing reduces infiltration and promotes runoff that can become abundant on the slopes. Studies conducted at the watershed scale have shown that soil loss increases when the vegetation decreases [44]. Bare areas are subject to erosion, while the vegetated areas are protected [45].

The $\mathrm{C}$ factor value depends on the nature of the vegetation and the percentage of vegetation cover. The latter can be estimated by the normalized difference vegetation index (NDVI) [46].

We calculated the index of vegetation cover from the supervised classification of Landsat satellite images 8 OLI covering the entire area. According to the following equation;

$\mathrm{NDVI}=\left(\frac{\mathrm{NIR}-\mathrm{RED}}{\mathrm{NIR}+\mathrm{RED}}\right)$

where NIR is the near-infrared and RED is the red band.

The maximum value reflects the highest percentage of vegetation cover and also represents the condition of the vegetation. The areas without vegetation (bare soil and water bodies) have low NDVI value [47].

After calculating the NDVI, we calculated C Factor according to the following formula [48];

$\mathrm{C}=\mathrm{e}^{-\alpha\left(\frac{\mathrm{NDVI}}{\beta-\mathrm{NDVI}}\right)}$

where $\mathrm{a}$ and $\mathrm{b}$ are parameters without unity that determine the shape of the curve related to NDVI and Cfactor, An $\alpha$-value of 2 and a $\beta$-value of 1 seem to give reasonable results, according to [49].

The map of the $\mathrm{C}$ factor is generated using "Raster calculator" found using the module "Spatial Analysis" ArcGIS 10.2.

\section{Support practices factor $P$}

The $\mathrm{P}$ factor described conservative soil human actions which are practiced to counteract water erosion. $\mathrm{P}$ values generally range from 0 to 1 , according to the practice and depending on the slope [50].

According to the regional directorate of water and forests and the fight against desertification (Casablanca, Morocco), the erosion control measures already undertaken at the watershed of Oued El Malleh are biological measures (reforestation and improved forest grazing) and mechanical actions such as the construction of the thresholds for the correction of ravines.

\section{Results and discussion}

\section{Erosivity factor $(\mathbf{R})$}

The data of rainfall over 20 years (2000 - 2019) were obtained from the Agency of Basin Hydraulic Bouregreg and Chaouia from several weather stations (Hassar dam, Malleh dam, Melilla, El Gara, Oueljet Haboub, Feddan Taba and Tamesna) and were imported into a geographic information system (GIS) since all the weather stations have geographic coordinates. The annual and monthly rainfall data of the catchment of Oued El Malleh basin were used to calculate the R factor in this study.

This factor was calculated separately for each separate station, and then we interpolated the results by the method of interpolation "Kriging" software Arcgis 10.2, for the erosivity factor of the map of El Oued Malleh watershed.

The rainfall erosivity (R-factor) increases from upstream to downstream of the watershed of Oued El Malleh. The R factor values range from 45.85 to 120.11 (MJ.mm.ha ${ }^{-1} \cdot \mathrm{h}^{-1} \cdot \mathrm{y}^{-1}$ ) with an average of 76.52 (MJ.mm.ha ${ }^{-1} \cdot \mathrm{h}^{-1} \cdot \mathrm{y}^{-1}$ ). For $81 \%$ of the surface area of the Oued El Malleh catchment area, low $\mathrm{R}$ values (45.85 to 88.37 MJ.mm.ha ${ }^{-1} \cdot \mathrm{h}^{-1} \cdot \mathrm{y}^{-1}$ ) are established upstream and in

The centre of the catchment area where the 3 weather stations are located: Melilla, El Gara and Tamesna, while higher values (88.37 to 120.11 MJ.mm.ha $\left.\mathrm{h}^{-1} \cdot \mathrm{h}^{-1} \cdot \mathrm{y}^{-1}\right)$ are assigned downstream of the watershed with an area of $18 \%$ (Table 3, Figure 5). Therefore, we deduce that the erosive power of rainfall is important in this basin, which knows an increasing gradient from north to northeast. 
These values are relatively in the line with those found in the same watershed that indicates values ranging from 62.59 to 104.63 [24] and those Oued El Makhazine determined values of 74.63 and 116.11 [29] and are larger than those obtained in the Isly watershed (44 to 56) in the eastern part of Morocco [51], those obtained in the watershed Moulay Bouchta (63 to 79) in the Rif Occidental [52], in contrast, these values are lower than those found in the Telata basin from 215 and 228 (MJ.mm.ha ${ }^{-1} \cdot \mathrm{h}^{-1} \cdot \mathrm{y}^{-1}$ ) [53].

Table 3 and Figure 5 evaluate the index of erosivity (R) of rainfall for 20 years watershed Oued El Malleh, from 2000 to 2019.

\section{Erodibility factor (K)}

As defined in Eqs. (6) - (10), there were obtained the values of the factor $\mathrm{K}$ in (Table 4). and Figure 6 shows the spatial distribution of the K-factor with soil type and the total area of the watershed, as follows;

1) Upstream, downstream and part in the centre, the erodibility is high with a value of 0.0183 t.ha.h.ha ${ }^{-1} \cdot \mathrm{MJ}^{-1} \cdot \mathrm{mm}^{-1}$ given to the most erodible soils such as Chromic Luvisols soils (LC), covering an area of $58.42 \%$ of the total area of the watershed.

2) In the Northwest and Southeast ends of the watershed, soil erodibility is below 0.0168 t.ha.h.ha ${ }^{-1} \cdot \mathrm{MJ}^{-1} \cdot \mathrm{mm}^{-1}$ these places are mostly made up of the most resistant to erosion namely.

3) vertisols (V), calcic cambisols Luvic (BK) with an area of about $16.21 \%$. In general, the soils of the watershed of Oued El Malleh are of great sensitivity to erosion.

Table 2 Rainfall erosivity from 2000 to 2019.

\begin{tabular}{|c|c|c|c|c|c|}
\hline Station & $X(m)$ & $\mathbf{Y}(\mathbf{m})$ & $\begin{array}{c}\text { Annual } \\
\text { average P } \\
(\mathbf{m m})\end{array}$ & $\mathbf{F}$ & R (MJ.mm.ha $\left.{ }^{-1} \cdot h^{-1} \cdot y^{-1}\right)$ \\
\hline Hassar Dam & 310900 & 332700 & 367.75 & 59.16 & 120.14 \\
\hline FeddanTaba & 333600 & 331200 & 422.00 & 57.55 & 115.27 \\
\hline OuljetHaboub & 420200 & 279300 & 329.86 & 36.36 & 57.88 \\
\hline Tamesna & 341350 & 291000 & 234.98 & 31.12 & 45.83 \\
\hline $\begin{array}{l}\text { El Malleh } \\
\text { Dam }\end{array}$ & 319700 & 324900 & 374.73 & 50.67 & 95,21 \\
\hline El Gara & 328700 & 298800 & 290.49 & 38.79 & 63.79 \\
\hline Melilla & 335900 & 310300 & 218.83 & 31.64 & 46.99 \\
\hline
\end{tabular}

Key: $\mathrm{P}=$ Average annual rainfall $(\mathrm{mm}), \mathrm{F}=$ Fournier index, $\mathrm{R}=$ Erosivity factor 


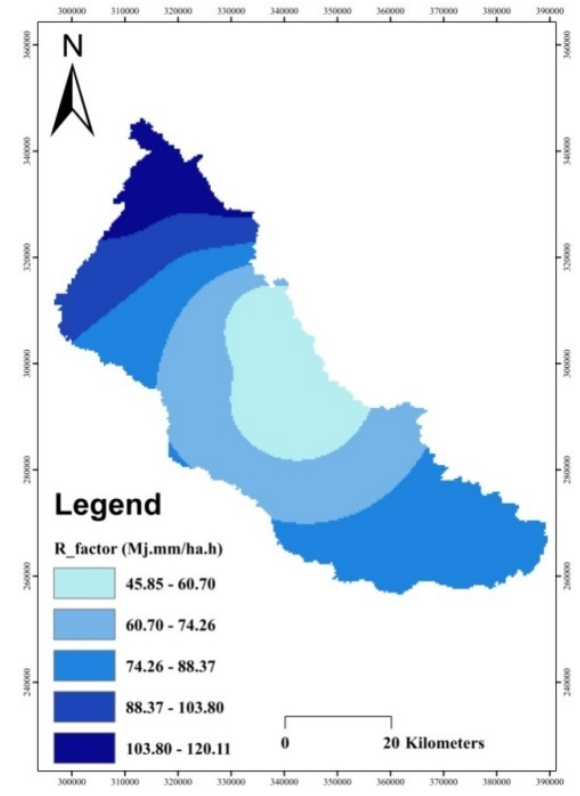

Figure 2 Rainfall erosivity map.

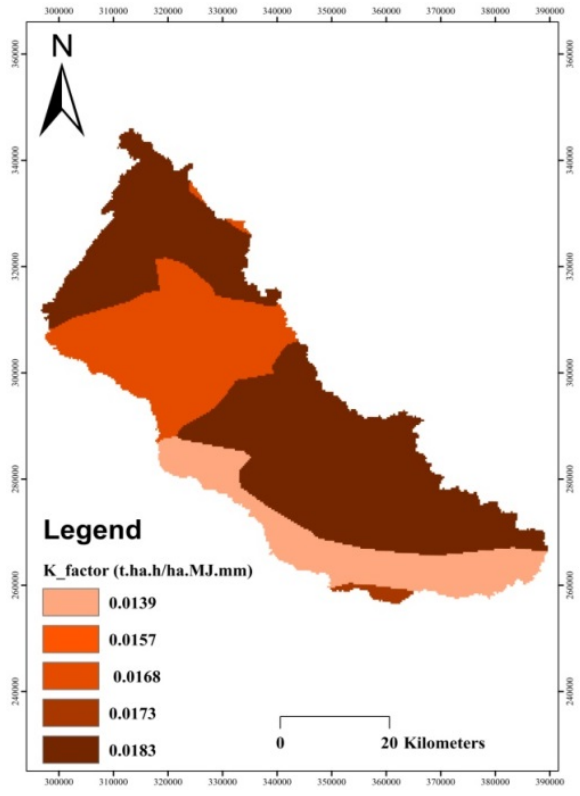

Figure 5 Rainfall erosivity map.

Table 4 Soil erodibility variation.

\begin{tabular}{|c|c|c|c|c|c|c|c|}
\hline Soil sample & fcsand & fcl-si & forgc & fhisand & k USLE & $\begin{array}{c}\mathrm{k} \\
\left(\mathrm{t} . h \mathrm{ha} \cdot \mathrm{h} \cdot \mathrm{ha}^{-1} \text {. }\right. \\
\mathrm{MJ}^{-1} \cdot \mathrm{mm}^{-1} \text { ) }\end{array}$ & Area \% \\
\hline $\begin{array}{c}\text { Eutric } \\
\text { Planosols } \\
(\mathrm{WE})\end{array}$ & 0.20000000 & 0.78178334 & 0.98962353 & 0.85020629 & 0.13155602 & 0.0173 & 0.003 \\
\hline $\begin{array}{c}\text { Chromic } \\
\text { luvisols (LC) }\end{array}$ & 0.20000010 & 0.72461527 & 0.97770189 & 0.98303377 & 0.13928764 & 0.0183 & 58.42 \\
\hline vertisols (V) & 0.20113147 & 0.60855151 & 0.97271759 & 0.99999586 & 0.11905903 & 0.0157 & 24.54 \\
\hline $\begin{array}{c}\text { calcic } \\
\text { cambisols } \\
(\mathrm{BK}) \\
\end{array}$ & 0.20000000 & 0.74062975 & 0.99060501 & 0.71847898 & 0.10542552 & 0.0139 & 16,21 \\
\hline $\begin{array}{c}\text { Luvic } \\
\text { Phaeozems } \\
(\mathrm{HL})\end{array}$ & 0.20014780 & 0.77832575 & 0.81894776 & 0.99990755 & 0.12756404 & 0.0168 & 0.83 \\
\hline
\end{tabular}

\section{Topography factor (LS)}

The LS factor shows the importance of the inclination and length of slope in the process of linear erosion (Figure 6). The relatively flat topography of the watershed of Oued El Malleh implies a distribution of moderate LS values between 0 and 97.33. With a small percentage of the values that are estimated high or higher than 23.7 and the mean of this factor on the whole watershed is assessed at 59 . We see that the LS values are less than 4.20 in the majority of the study area, and the slopes are weak and susceptible to erosion, except areas that have steep slopes, such as along river Oued El Malleh (LS exceeds 23.66) that reveal a greater sensitivity to erosion processes. These results agree with those made at the river Ourika basin (of 0.01 to 94.5) at the top Atlas of Morocco [55] and more important than those obtained in the same watershed ranging from 0.06 to 61.60 [24].

\section{Land cover factor $(C)$}

The spatial distribution map of plant coverage of the survey area shown in (Figure 7) reveals that the index of the plant covered $\mathrm{C}$ varies between 0.07 et 1 , with more than $69.27 \%$ of the entire watershed 
has good vegetation concern separate drills, moderate and dense indicating lower values ranging from 0.07 to 0.76 . Against $30 \%$ of the area of the watershed is related to bare soil and bodies of water, with a value between 0.76 and 1 . Almost one-third of this watershed area vulnerable to erosion is the one which covers the upstream part and central watershed.

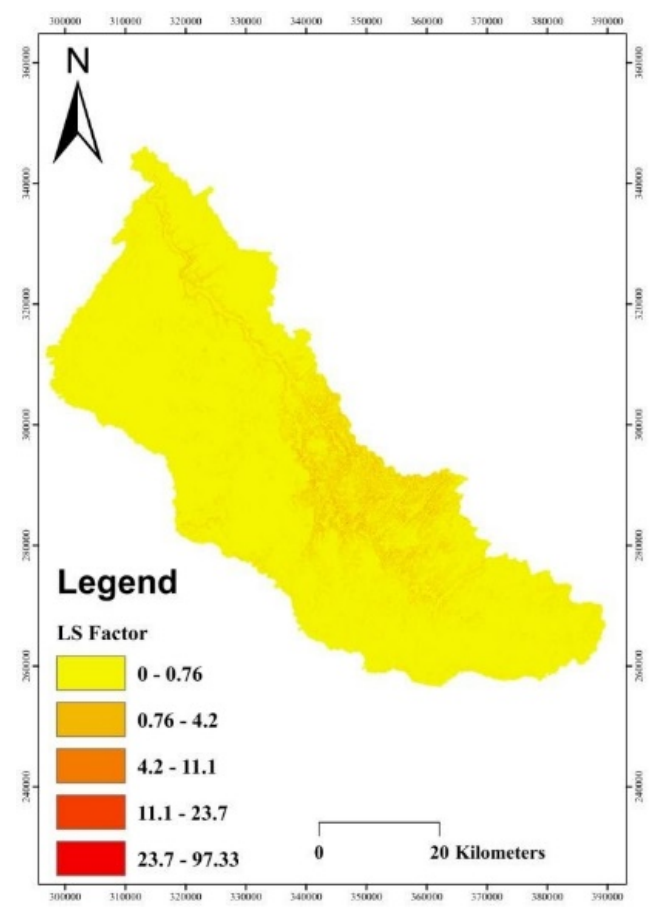

Figure 6 Length and Steepness Factor map.

Figure 7 Map of land use.

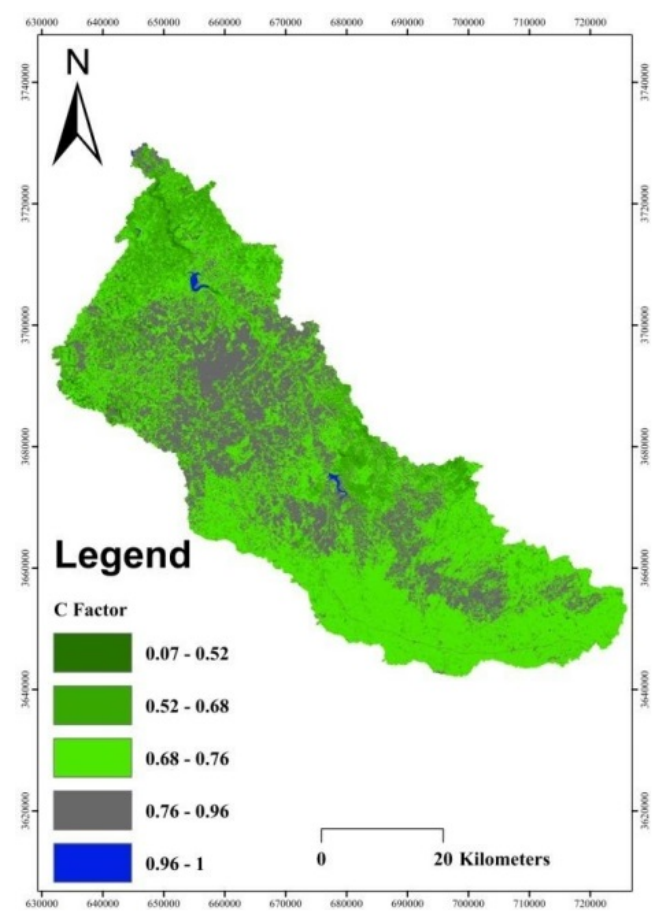




\section{Conservation practice factor $(\mathbf{P})$}

At Oued El Malleh watershed, there were no significant erosion control practices, almost $89 \%$ of the total surface area of the study area represents land without conservation practices (Figure 8), and therefore a value of 1 is attributed to P factor. Except for the 2 communes Ahlaf (at the level of the province of Benslimane) and Mgarto (at the level of the province of Settat) where biological treatments and thresholds are covering a small area of the order of $8.52 \%$.

The $\mathrm{P}$ factor values, respectively assigned to each commune 0.4 and 0.35 . It should be noted that in this study, the value of the P-factor for the biological and the mechanical treatment was determined according to $[55,56]$. Since more than $22.32 \%$ of the study area represents slope classes ranging from 7 to $21 \%$ medium-high (Figure 2), it is proposed to map the erosion control practices (Figure 9) according to the slope [57].

The values of the topographic factor vary between 0.55 and 0.6 for low slope areas $(72 \%$ of the total catchment area), between 0.6 and 0.9 for medium steep areas ( $21 \%$ of the total area) and between 0.9 and 1 for steep slope areas.

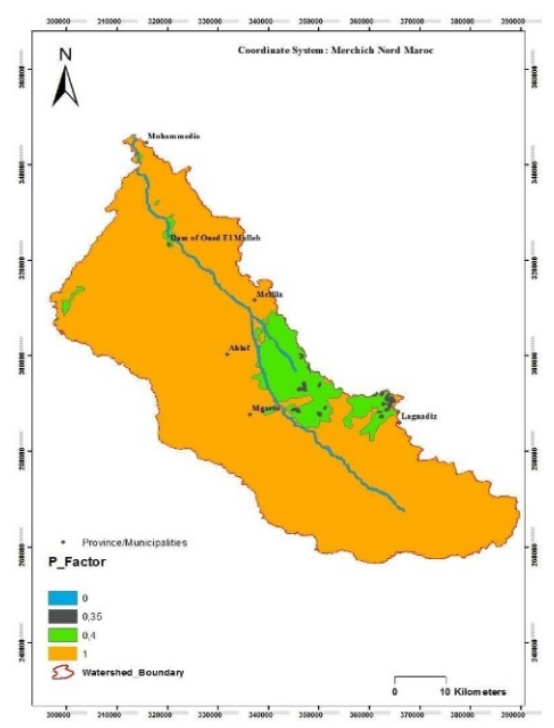

Figure 8 Map of anti-erosion practices according to the regional directorate of water and forests and the fight against desertification in Casablanca, Morocco.

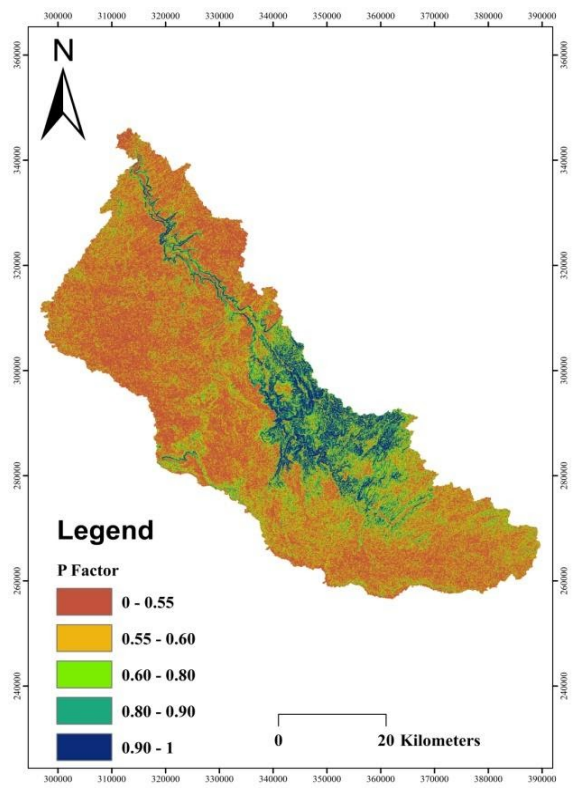

Figure 9 Map of anti-erosive practices according to the slope. 


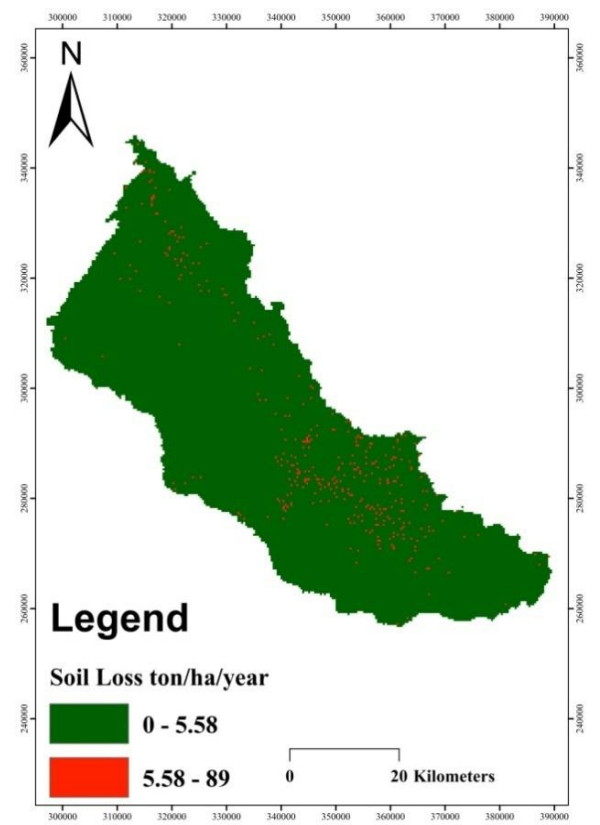

Figure 10 Soil losses with anti-erosion devices according to the regional directorate of water and forests and the fight against desertification in Casablanca, Morocco.

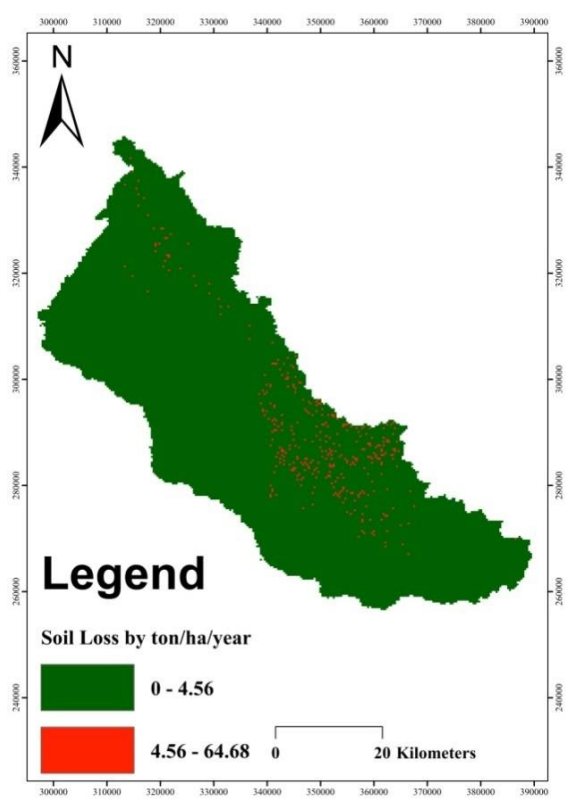

Figure 11 Soil loss with erosion control measures according to the slope.

\section{Average annual soil loss}

The combination of the USLE factors, namely climatic aggressiveness, soil erodibility, length and steepness slope, land cover, and erosion control practices into the ArcGIS model provides the resulting soil losses map. The final erosion soil map involved at any point in the watershed.

The average annual rate of soil erosion in the Oued El Malleh watershed is estimated to be $0.65 \mathrm{t}$. ha $^{1}$.year ${ }^{1}$, with no significant support practices, resulting in annual losses of 203,255 tons of soil. However, soil losses vary from 0.5 tha $^{1}$.year ${ }^{1}$ to 89 t. ha $^{1}$.year ${ }^{1}$ (Figure 10). This result is not comparable with other studies carried out in the same catchment area [24], where the maximum and minimum losses

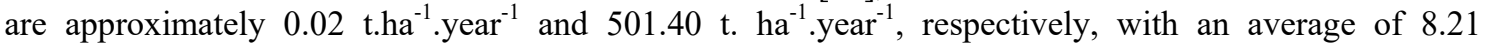


t.ha ${ }^{1}$.year ${ }^{1}$. This was because of the inter-annual irregularity at the meteorological stations. The resulting values are most relevant than thus obtained by including the factor of anti-erosion practices $\mathrm{P}$ estimated according to [57] (Figure 9) in the overlay of the maps, with minimum values of 0 t.ha $^{1}$.year ${ }^{1}$ and maximum values of $65 \mathrm{t}^{-\mathrm{ha}^{1} \text {.year }}{ }^{1}$, with an average of 0.4 (Figure 11). The soil losses finding displays the importance of support practices on decreasing soil losses, as well as the inefficiency of the existing conservation practices to restricting the soil degradation in the Oued El Malleh catchment. This can be explained by floods that hamper the catchment area during the winter period [26]. For this reason, it is essential to monitor erosion control measures after rainstorm periods, especially during the winter period. Moreover, the watershed topography impact more and more the number of losses, about $1.4 \%$ of soil losses are severe, i.e. 4355 ha are much degraded and the losses are highest, against 300,710.88 ha with moderate intensity. Meanwhile, the bathymetric survey from 1988 to 2004 shows that the loss of the reservoir capacity storage is about $0.24 \mathrm{Mm}^{3}(0.9 \mathrm{t} / \mathrm{ha} /$ year $)$, which indicates that the soil loss results are reasonable. Comparing this result with simulated values demonstrates that the USLE model underestimates the soil erosion in the Oued El Malleh watershed. This finding is in agreement with [59$61]$.

The annual rate of erosion shown on the map (Figure 11) shows that areas of high erosive risk increase with slope inclination (greater than $53 \%$ ), generally concentrated at the level of hilly landscapes especially along the Oued El Malleh lake and its tributaries ( Hassar Wadi, Zamrine wadi, Ateuch wadi). With intense soil loss ranging from $5.6 \mathrm{t}^{\mathrm{ha}} \mathrm{h}^{1}$.year ${ }^{1}$ to $90 \mathrm{t}$. $\mathrm{ha}^{-1}$.year ${ }^{-1}$, this is aided by the impact of the topographic factor coinciding with strong values (from 11 to 97), accentuated by aggressive precipitation with an R factor ranging from 75 to $120 \mathrm{MJ} \cdot \mathrm{mm} \cdot \mathrm{ha}^{-1} \cdot \mathrm{h}^{-1} \cdot \mathrm{y}^{-1}$, with generally the strongest increases in drainage density, as a result of the decline in vegetation cover ranging from 0.76 and 1 , this is mainly explained by the dominance of rangelands degraded by anthropogenic actions and agriculture (dryland farming) which are considered the most vulnerable to erosion, representing $88 \%$ of the total area of the watershed, With a lack of cultural practices, which make it possible to reduce the impact of the loss on erosion and to fix the soil, except a few hectares planted with sylvo-pastoral crops and dry stone.

Water erosion is moderate, on low-slope areas extending over $75 \%$ of the total catchment area and low soil erodibility due to the high percentage of sand. In addition, tree formations, matorral and rangelands help to control climatic aggressiveness and increase soil protection by intercepting part of the rainfall.

Land degradation by water erosion is steadily worsening in the Oued El Malleh catchment, showing the inefficiency of the actual measures. Thereby, new soil conservation interventions and measures should be done. This approach is proving to be extremely urgent. It follows that we propose mechanical and biological treatments according to the intensity of the topography of the Oued El Malleh watershed;

1) Weak slopes (less than $13 \%$ ) can be consolidated into stony cordons, when the plot is located in the bed of a gully, to facilitate infiltration and slow down runoff.

2) On medium to steep slopes (up to $15 \%$ ), stone walls can be built (preferably local stones transported by cart), this technique reduces runoff and its speed and traps the transported sediment.

Then, implement biological management in areas of high erodibility, by improving rangelands and croplands, maintaining old plantations and reforesting trees or shrubs. Trees promote water infiltration and prevent runoff through their root system, and therefore sustain the stability of the soil structure.

\section{Conclusions}

The catchment area of Oued El Malleh is favourable to the development of risks of water erosion due to the intensity of rainfall in its large part, associated with steep slopes, moderately permeable soil (sandy clay to clayey clay) and dilapidated vegetation.

This degradation of the vegetation cover is characterized by the scarcity of the forest estate, which protects the soil structure well through its root system, and the dominance of agriculture, which protects the soil less, resulting in significant erosion runoff in the study area.

The result of this runoff is considered to be the main contributor to the high amounts of water erosion, estimated 28 million tons annually. This quantity of eroded soil gives rise to an estimated sediment yield of 2,586,029 (t.year ${ }^{-1}$ ), and the specific degradation is 8.27 t.ha $^{1}$.year ${ }^{1}$, obtained with a delivery coefficient of $0.6 \%$.

The intensity of soil losses in the Oued El Malleh watershed has visible effects on the environment (silting of the Oued El Malleh dam and impoverishment of its quality). Soil degradation in the study area may become severe, if preventive and curative actions are not taken, i.e. the implementation of anti- 
erosion facilities depending on the slope and geological context (hard and soft rocks). However, these steps may be unfavourable, given that the catchment area is made up of privately owned land.

Finally, the implementation of the universal soil loss equation using Geographic Information System (GIS) allows the assessment of the potential risk of large-scale erosion. Nevertheless, the model underestimates the actual soil loss, which seems normal because the model does not take into account other forms of erosion, especially since the Oued El Malleh watershed has experienced severe flooding in 1999 and 2002. It is a simple and inexpensive aid tool for modelling and mapping soil erosion, especially for inaccessible areas where field measurements are rare or even non-existent.

\section{Acknowledgements}

I would like to thank and express our appreciation to the staff of the River Basin Agency of Bouregreg and Chaouia for their cooperation in providing all data required for this study.

\section{References}

[1] R Lal. Soil erosion impact on agronomic productivity and environment quality. Crit. Rev. Plant Sci. 1998; 17, 319-464.

[2] A Boudhar, B Duchemin, L Hanich, A Chaponnière, P Maisongrande, G Boulet, J Stitou and A Chehboun. Analyse de la dynamique des surfaces enneigées du Haut Atlas marocain à partir des données SPOT-VEGETATION. Sécheresse 2007; 18, 278-88.

[3] K Vezina, F Bonn and PV Cu. Agricultural land-use patterns and soil erosion vulnerability of watershed units in Vietnam's northern highlands'. Landsc. Ecol. 2006; 21, 1311-25.

[4] R Parveen and U Kumar. Integrated approach of Universal Soil Loss Equation (USLE) and Geographical Information System (GIS) for soil loss risk assessment in Upper South Koel Basin, Jharkhand. 2012; 4, 588-96.

[5] TA Adongo, JX Kugbe and VD Gbedzi. Siltation of the reservoir of Vea irrigation dam in the Bongo district of the Upper East Region, Ghana. 2014; 4, 1-7.

[6] WH Wischmeier and DD Smith. Predicting rainfall erosion losses: A guide to conservation planning. Department of Agriculture, Science and Education Administration, 1978.

[7] KG Renard, GR Foster, GA Weesies, DK McCool and DC Yoder. Predicting Soil Erosion by Water: A Guide to conservation planning with the Revised Universal Soil Loss Equation (RUSLE). United State Department of Agriculture, Washington DC, 1997.

[8] KP Bhandari and R Darnsawasdi. Application of remote sensing and participatory soil erosion assessment approach for soil erosion mapping in a watershed. Walailak J. Sci. Tech. 2015; 12, 689702.

[9] AE Bilali, T Abdeslam, BE Idrissi, Y Brouziyne and N Mazigh. Comparison of a data-based model and a soil erosion model coupled with multiple linear regression for the prediction of reservoir sedimentation in a semi-arid environment. Euro-Mediterr. J. Environ. Integr. 2020; 5, 64.

[10] C Alewell, P Borrelli, K Meusburger and P Panagos. Using the USLE: Chances, challenges and limitations of soil erosion modelling. Int. Soil Water Conserv. Res. 2019; 7, 203-25.

[11] N Shivhare, PKS Dikshit and SB Dwivedi. A comparison of SWAT model calibration techniques for hydrological modeling in the Ganga River Watershed. Engineering. 2018; 4, 643-52.

[12] VC Piscoya, WPD Souza, JRB Cantalice, MC Filho, RCPD Melo and RNDA Filho. WEPP Model for rill erosion estimation in a Brazilian Semiarid Watershed. Rev. Caatinga. 2020; 33, 835-43.

[13] N Baggaley and J Potts. Sensitivity of the PESERA soil erosion model to terrain and soil inputs. Geoderma Reg. 2017; 11, 104-12.

[14] Y Bouslihim, A Rochdi and NEA Paaza. Combining SWAT model and regionalization approach to estimate soil erosion under limited data availability conditions. Eurasian Soil Sci. 2020; 53, 128092.

[15] CJLM Falcão, SMDA Duarte and ADS Veloso. Estimating potential soil sheet Erosion in a Brazilian semiarid county using USLE, GIS, and remote sensing data. Environ. Monit. Assess. 2020; 192, 47.

[16] J Wu and J Lu. Spatial scale effects of landscape metrics on stream water quality and their seasonal changes. Water Res. 2021; 191, 116811.

[17] T Rodrigues, E Alcântara, L Rotta, N Bernardo and F Watanabe. An investigation into the relationship between light absorption budget and trophic status in inland waters. Ecol. Indic. 2020; 115, 106410. 
[18] JJ Chevalier, J Pouliot, K Thomson and MR Boussema. Systèmes d'aide à la planification pour la conservation des eaux et des sols (Tunisie). Systèmes d'information géographique utilisant les données de télédétection. Actes du Colloque Scientifique International, Hammamet, Tunisie, 1994.

[19] AA Fora. 1995, Spatial modeling of water erosion in a Moroccan rock watershed: Validation of the geomatic approach by sedimentology, radioactive tracers and magnetic susceptibility of sediments. $\mathrm{Ph}$. D. Dissertation. Université de Sherbrooke, Sherbrooke, Canada.

[20] A Lahlou. Specific degradation of watershed in Morocco. Report $n^{\circ} 1000$, Ministry of Equipment and National Promotion, water direction, exploitation division. Water Management Service, Rabat, 1977.

[21] $\mathrm{O}$ Mhirit and $\mathrm{F}$ Benchekroun. Les écosystèmes forestiers et périforestiers: Situation, enjeux et perspectives pour 2025. Rapp. Général. 2006; 50, 395-468.

[22] M Tahri, A Merzouk, HF Lamb and RW Maxted. Etude de l'erosion hydrique dans le plateau d'imelchil dans le Haut-Atlas central utilisation d'un S.I.G. d'érosion. GEO Observateur 1993; 3, 5160 .

[23] T Merzouki. Diagnostic de l'envasement des grands barrages marocains. Rev. Marocaine Génie Civ. 1992; 38, 4650.

[24] H Lahlaoi, H Rhinane, A Hilali, S Lahssini and L Khalile. Potential erosion risk calculation using remote sensing and GIS in Oued El Maleh Watershed, Morocco. J. Geogr. Inf. Syst. 2015; 7, 128.

[25] K Abdelouafi, W Annouar, D Lahcen and E Samira. 2012, Quantification de l'érosion hydrique linéaire dans le bassin versant d'Oued El Malleh: Cas du micro bassin de Sidi Sbea. Mémoire de fin d'études, Faculté des Sciences et Techniques Marrakech, Marrakech, Maroc, p. 66.

[26] AE Bilali, A Taleb and I Boutahri. Application of HEC-RAS and HEC-LifeSim models for flood risk assessment. J. Appl. Water Eng. Res. 2021; 9, 336-51.

[27] WH Wischmeier and DD Smith. A universal soil-loss equation to guide conservation farm planning. Trans. $7^{\text {th }}$ Int. Congr. Soil Sci. 1960; 1, 418-25, 1960.

[28] O Cerdan. Guide méthodologique pour un zonage départemental de l'érosion des sols. Rapport $n^{\circ}$ 3: Synthèse et recommandations générales. Bureau de Recherches Géologiques et Minières, France, 2006.

[29] HEH Hassan, L Charbel and L Touchart. Modélisation de l'érosion hydrique à l'échelle du bassin versant du Mhaydssé. Békaa-Liban. VertigO 2018; 18, 19804.

[30] A Belasri and A Lakhouili. Estimation of soil erosion risk using the universal soil loss equation (USLE) and geo-information technology in Oued El Makhazine Watershed, Morocco. J. Geogr. Inf. Syst. 2016; 8, 98-107.

[31] G Team. GeoNetwork opensource portal to spatial data and information, Available at: http://www.fao.org/geonetwork/srv/en/metadata.show?id=14116, accessed August, 2020.

[32] TG Farr, PA Rosen, E Caro, R Crippen, R Duren, S Hensley, M Kobrick, M Paller, E Rodriguez, L Roth, D Seal, S Shaffer, J Shimada, J Umland, M Werner, M Oskin, D Burbank and D Alsdorf. The shuttle radar topography mission. Rev. Geophys. 2007; 45, RG2004.

[33] G Boggs, C Devonport, K Evans and P Puig. GIS-based rapid assessment of erosion risk in a small catchment in the wet/dry tropics of Australia. Land Degrad. Dev. 2001; 12, 417-34.

[34] CEP Cerri, JAM Demattě, MVR Ballester, LA Martinelli, RL Victoria and E Roose. GIS Erosion risk assessment of the Piracicaba River Basin, Southeastern Brazil. Mapp. Sci. Rem. Sens. 2001; 38, 157-71.

[35] RA Shakesby, COA Coelho, S Schnabel, JJ Keizer, MA Clarke, JFL Contador, RPD Walsh, AJD Ferreira and SH Doerr. A ranking methodology for assessing relative erosion risk and its application to dehesas and montados in Spain and Portugal. Land Degrad. Dev. 2002; 13, 129-40.

[36] R Kheir, A Shaban, MC Girard and M Khawlie. Impact des activités humaines sur l'érosion hydrique des sols dans la région côtière montagneuse du Liban. Sécheresse 2001; 12, 157-65.

[37] HMJ Arnoldus. Methodology used to determine the maximum potential average annual soil loss due to sheet and rill erosion in Morocco. FAO Soils Bull. 1977; 34, 39-48

[38] L Hui, C Xiaoling, KJ Lim, C Xiaobin and M Sagong. Assessment of soil erosion and sediment yield in Liao watershed, Jiangxi Province, China, Using USLE, GIS, and RS. J. Earth Sci. 2010; 21, 941-53.

[39] JR Williams. The EPIC model. In: VP Singh (Ed.). Computer models of watershed hydrology. Water Resources Publications, Highlands Ranch, CO, 1995, p. 909-1000.

[40] E Roose. Introduction à la gestion conservatoire de l'eau, de la biomasse, et de la fertilité des sols (GCES). FAO, Montpellier, France, 1999, p. 420.

[41] N Hudson. Soil conservation. BT Batsford, London, 1973. 
[42] AW Zingg. Degree and length of land slope as it affects soil loss in run-off. Agr. Eng. 1940; 21, 5964.

[43] E Payet, P Dumas and G Pennober. Modélisation de l'érosion hydrique des sols sur un bassin versant du sud-ouest de Madagascar, le Fiherenana. VertigO 2012; 11, 12591.

[44] RB Kheir. 2002, Etude des risques d'érosion hydrique des sols par télédétection et SIG: Application à une région représentative du Liban. Ph. D. Dissertation. Institut national agronomique Paris Grignon, Paris, France.

[45] MC Battany and ME Grismer. Rainfall runoff and erosion in Napa Valley vineyards: Effects of slope, cover and surface roughness. 2000; 14, 1289-304.

[46] KD Reid, BP Wilcox, DD Breshears and L MacDonald. Runoff and erosion in a piiion-juniper woodland: Influence of vegetation patches. Soil Sci. Soc. Am. J. 63, 1869-79.

[47] S Toumi, M Meddi, G Mahé and YT Brou. Cartographie de l'érosion dans le bassin versant de l'Oued Mina en Algérie par télédétection et SIG', Hydrol. Sci. J. 2013; 58, 1542-58.

[48] R Caloz and C Collet. Précis de télédétection - Volume 3: Traitements numériques d'images de télédétection. Presses de l'Université du Québec, Quebec, Canada, 2001.

[49] JMVD Knijff, RJA Jones and L Montanarella. Soil erosion risk assessment in Europe. European Soil Bureau, Ispra, Italy, 2000.

[50] MVD Knijff, RJA Jones and L Montanarella. 'lao', EUR19022. European Soil Bureau, Ispra, Italy, 1999.

[51] A Laouina. 'dri'. Publ FLSH University Mohammed V Agdal Rabat, Rabat, Morocco, 2007.

[52] EH Driss and A Brahim. Quantification de l'erosion hydrique en utilisant le modèle rusle et déposition intégrée dans un sig. cas du bassin versant de l'oued isly (Maroc Oriental). Eur. Sci. J. $2018 ; 14,373$.

[53] A Zouagui, M Sabir, M Naimi, M Chikhaoui and M Benmansour. Modelisation du risque d'érosion hydrique par l'équation universelle des pertes en terre dans le rif occidental: Cas du bassin versant de moulay bouchta (Maroc). Eur. Sci. J. 2018; 14, 524.

[54] L Dhman, A Merzouk, M Sabir and I Fenjiro. Cartographie des pertes en terre dues à l'érosion hydrique par utilisation d'un système d'information géographique et des images satellites. Cas du bassin versant de Telata (Maroc). Atelier Trav. Sur Modélisation L'érosion Hydr. Par RUSLE. 1997, p. 52-65.

[55] M Modeste, K Abdellatif, M Nadia and H Zhang. cartographie des risques de l'erosion hydrique par l'equation universelle revisee des pertes en sols, la teledetection et les sig dans le bassin versant de l'ourika (Haut Atlas, Maroc). Eur. Sci. J. 2016; 12, 277.

[56] P Roy. Application of USLE in a GIS environment to estimate soil erosion in the Irga watershed, Jharkhand, India. Phys. Geogr. 2019; 40, 361-83.

[57] C Lin, R Ma and B He. Identifying watershed regions sensitive to soil erosion and contributing to lake eutrophication: A case study in the Taihu Lake Basin (China). Int. J. Environ. Res. Publ. Health. 2015; 13, 77.

[58] GJ Shin. 1999, The analysis of soil erosion analysis in watershed using GIS. Ph. D. Dissertation. Department of Civil Engineering, Gangwon National University. Chuncheon, South Korea.

[59] B Bagio, I Bertol, NH Wolschick, D Schneiders and MADND Santos. Water erosion in different slope lengths on bare soil. Rev. Bras. Ciênc. Solo. 2017; 41, e0160132.

[60] V Bagarello, V Ferro and D Flanagan. Predicting plot soil loss by empirical and process-oriented approaches. A review. J. Agr. Eng. 2018; 49, 1-18.

[61] M Manaouch, A Zouagui and I Fenjiro. A review of soil erosion modeling by R/USLE in Morocco: Achievements and limits. E3S Web Conf. 2021; 234, 00067. 